\title{
Teaching the Elephant to Dance: Privatizing the FDA Review Process
}

\author{
Elizabeth Price Foley \\ Florida International University College of Law \\ Elizabeth C. Price \\ Florida International University College of Law
}

Follow this and additional works at: https://ecollections.law.fiu.edu/faculty_publications

Part of the First Amendment Commons, and the Food and Drug Law Commons

\section{Recommended Citation}

Elizabeth Price Foley and Elizabeth C. Price, Teaching the Elephant to Dance: Privatizing the FDA Review Process , 51 Food \& Drug L.J. 651 (1996).

Available at: https://ecollections.law.fiu.edu/faculty_publications/419 


\section{HEINONLINE}

DATE DOWNLOADED: Sun Jul 19 16:12:49 2020

SOURCE: Content Downloaded from HeinOnline

Citations:

Bluebook 20th ed.

Elizabeth C. Price, Teaching the Elephant to Dance: Privatizing the FDA Review Process, 51 Food \& Drug L.J. 651 (1996).

ALWD 6th ed.

Elizabeth C. Price, Teaching the Elephant to Dance: Privatizing the FDA Review

Process, 51 Food \& Drug L.J. 651 (1996).

APA 7th ed.

Price, E. C. (1996). Teaching the elephant to dance: Privatizing the fda review process. Food and Drug Law Journal, 51(4), 651-676.

Chicago 7th ed.

Elizabeth C. Price, "Teaching the Elephant to Dance: Privatizing the FDA Review

Process," Food and Drug Law Journal 51, no. 4 (1996): 651-676

McGill Guide 9th ed.

Elizabeth C Price, "Teaching the Elephant to Dance: Privatizing the FDA Review

Process" (1996) 51:4 Food \& Drug LJ 651.

MLA 8th ed.

Price, Elizabeth C. "Teaching the Elephant to Dance: Privatizing the FDA Review

Process." Food and Drug Law Journal, vol. 51, no. 4, 1996, p. 651-676. HeinOnline.

OSCOLA 4th ed.

Elizabeth C Price, 'Teaching the Elephant to Dance: Privatizing the FDA Review

Process' (1996) 51 Food \& Drug LJ 651

Provided by:

FIU College of Law

-- Your use of this HeinOnline PDF indicates your acceptance of HeinOnline's Terms and Conditions of the license agreement available at https://heinonline.org/HOL/License

-- The search text of this PDF is generated from uncorrected OCR text.

-- To obtain permission to use this article beyond the scope of your license, please use: Copyright Information 


\title{
Teaching the Elephant to Dance: Privatizing the FDA Review Process
}

\author{
Elizabeth C. Price*

\section{INTRODUCTION}

In 1991, David Kessler, J.D., M.D., became Commissioner of the U.S. Food and Drug Administration (FDA), the mammoth federal agency charged with overseeing products that generate over $\$ 1$ trillion in annual revenues and which account for twentyfive cents out of every dollar spent by the American consumer. ${ }^{1}$ Kessler became the caretaker of a wounded giant: the agency's image had been tarnished by the generic drug scandal, ${ }^{2}$ and years of budget cutbacks had siphoned its resources so severely that the industries it regulated and patient advocacy groups who suffered from the resulting slow review pace boldly had begun to complain ${ }^{3}$ Despite the controversy swirling around him, Kessler promised Congress and the American public that he "would teach the elephant to dance."4

Five years after Commissioner Kessler made his ambitious declaration, the elephant has begun swaying to the music, but has as yet to dance. Today the FDA is an overworked and underfed beast of burden charged with the life-or-death responsibility of reviewing almost 300 backlogged food additive petitions, ${ }^{5}$ as well as over 100 new drug applications (NDAs) ${ }^{6}$ and 7000 medical device applications ${ }^{7}$ each year. Accusations that the FDA is overly cautious, partisan, and vindictive against those critical of its methods have found a new, sympathetic ear in a Republican Congress intent on shrink-

- Ms. Price is Associate Professor, Detroit College of Law, Michigan State University. The author would like to express special appreciation to Professor Peter Barton Hutt of the law firm of Covington \& Burling, Washington, D.C., and Harvard Law School, a long-time friend and occasional nemesis, whose comments and wealth of experience were invaluable in the preparation of this article. Special thanks also are due to U.S. Senator Ron Wyden, a mentor and former employer, who provided a healthy dose of political perspective and encouragement. All opinions and errors contained within are exclusively the author's.

' President Bill Clinton \& Vice President Al Gore, National Performance Review: Reinventing Drug \& Medical Device Regulations 2 (1995) [hereinafter Nat'l Performance Review]; see also http:/ www.fda.gov/bbs/topics/ NEWS/NEW00414.html (FDA home page).

${ }^{2}$ See generally FDA's Generic Drug Approval Process (Parts 1-3), Hearings Before the Subcomm. on Oversight and Investigations of the House Comm. on Energy \& Commerce, 101st Cong., 1st Sess. (1989).

${ }^{3}$ See, e.g., Gallup Poll Says FDA Backlog of Device Reviews Jeopardizes Patients \& Jobs, BıMEDICAL Market NewsL., June 1994, available in LEXIS, NEXIS Library, News File, Nwltrs Subfile; The FDA Food Additive Review Process: Backlog and Failure to Observe Statutory Deadline: Fourth Report by the Comm. on Gov't Reform and Oversight, 104th Cong., Ist Sess. 6-10 (Dec. 21, 1995) [hereinafter Food Additive Hearing]; Gina Kolata, An Angry Response to Actions on AIDS Spurs FDA Shifi, N.Y. TimES, June 26,1988 , at 22. 48.

${ }^{4}$ See Henry Miller, Anti-Medicine Man: Commissioner David A. Kessler, NaT'L Rev., Oct. 9, 1995, at

${ }^{5}$ Food Additive Hearing, supra note 3, at 7.

${ }^{6}$ See General Accounting Office, FDa Drug Approval: Review Time has Decreased in Recent Years 5 (1995) (revealing that in the years 1987 to 1994, the FDA received a low of 87 NDAs in 1993, a high of 142 NDAs in 1987, and 118 NDAs in 1994).

7 See General Accounting Office, Medical Devices: FDA Review Time 6 (1995) (noting that 510(k) applications ranged from a high of 7023 in 1989 to a low of 5774 in 1991, and that $510(\mathrm{k})$ applications totaled 6446 in 1994); see also id. at 9 (noting that the FDA received 43 premarket approval (PMA) applications and 372 PMA supplements in 1994). 
ing virtually all facets of the federal government. Led by Speaker of the House Newt Gingrich (R-Ga.), who publicly has called Commissioner Kessler "a thug and a bully"8 and has labeled the FDA the "leading job killer" in America today, ${ }^{9}$ the new Republican Congress has launched a virtual jihad against the FDA, demanding comprehensive reform of the way the agency does business.

While FDA reform includes many different concepts, this article focuses on the most controversial of those concepts: "privatizing" the FDA's review function. More specifically, this article will explore the impact of removing, to a greater or lesser extent, the FDA's authority as the sole reviewer of the safety and efficacy of products that require premarket approval (food additives, ${ }^{10}$ prescription and over-the-counter drugs, ${ }^{11}$ biologics, ${ }^{12}$ and medical devices ${ }^{13}$ ). Part II of the article attempts to place the FDA reform movement in context by exploring the events that have provided the momentum for change. Part III sets forth the privatization proposals themselves, including bills pending before Congress and voluntary FDA initiatives. Part IV analyzes the likely impact of the various privatization proposals.

The article concludes that the most troubling flaw of the FDA - an institutional culture that breeds risk avoidance and an autocratic style of regulation - likely can be fixed, at least in the long run, only by breaking the FDA's regulatory monopoly and permitting third parties to participate in a competitive market for product review. If the elephant is ever going to dance, as Commissioner Kessler predicted, it must have an incentive to do so. Breaking the FDA's review monopoly and subjecting the agency to competition can provide the necessary incentive.

\section{BACKGROUND}

The FDA's lethargy is an ineluctable by-product of its monopolistic position. For those companies seeking to market new drugs, food additives, or medical devices, the FDA is the only game in town. As with any other monopolist, the FDA has unfettered ability to raise the "price" and limit the "supply" of its services (i.e., product approval), to force purchasers (i.e., product manufacturers) to engage in tying arrangements, ${ }^{14}$ and to boycott or refuse to deal with regulated entities. Furthermore, because there are no procompetitive virtues endemic to the FDA's monopolistic position that cannot also be achieved in a system of competing reviewers, perpetuating the FDA monopoly, with its resulting delays, inefficiency, and suboptimal allocation of scarce societal resources,

\footnotetext{
${ }^{8}$ See In Defence of the FDA, LANCET, Oct. 14, 1995, at 981.

'See The Assault on Government by Republicans, Progressive, Mar. 1995, at 8; Jeffrey P. Cohn, The "Bully" Fights Back, Gov'T ExEcutive, Apr. 1995, available in LEXIS, NEXIS Library, News File, Mags Subfile.

${ }^{10}$ See 21 U.S.C. $\$ 348$ (1994).

$"$ See id. $\$ 355$.

${ }^{12}$ See 42 U.S.C. $\$ 262$ (1994).

${ }^{13}$ See 21 U.S.C. $360 \mathrm{e}(\mathrm{b})$.

${ }^{14}$ For example, the FDA currently uses a "Reference List" of device manufacturers that have been found by the agency to have serious good manufacturing practice (GMP) violations. If a device manufacturer is on the FDA's "Reference List," the FDA generally will not approve any products by that manufacturer until the manufacturer agrees to correct the GMP violations. See Nat'L Performance Review, supra note 1, at 18-19. The FDA's not-so-subtle threat to withhold product approvals for device manufacturers with known GMP violations is analogous to a tying arrangement because it forces the device manufacturer to "buy" compliance with GMPs in order to "buy" the more desired item, product review. To put it another way, the FDA will "sell" its valued service of product review only if the device manufacturer also agrees to "buy" compliance with GMPs.
} 
may be more an anachronistic vestige of a "big government is better government" mentality than logic. ${ }^{15}$ To persuasively advocate the demise of the FDA monopoly, however, one must first pinpoint the adverse effects that such a monopolistic review system has on consumers and regulated industries, and then determine whether an alternative system of competitive review would alleviate or lessen those adverse effects.

\section{A. Lack of Effective Review of FDA Decisions}

When the FDA does act, its decisions, no matter how inchoate or enigmatic, are not reviewable in any practical sense. For example, imagine the most nefarious scenario in which: (1) the agency's action (or inaction) is objectively unjustifiable; and (2) the agency cloaks its decision in the rubric of safety or efficacy. In such a scenario, the affected company is unlikely to file suit to protect its interests for fear of antagonizing the FDA. After all, an angered agency could take an expensive and crucial product application and put it on the bottom of a four foot high stack of paper, where it likely will celebrate the beginning of the new millennium.

This scenario is more than just an impossible fiction. The current outrage over the way the FDA conducts business is not merely isolated grumbling by companies that want less regulation. There is a growing chorus of complaints that the FDA has acted vindictively against those openly critical of its methods and decisions. ${ }^{16} \mathrm{~A} 1991$ poll of companies regulated by the FDA conducted by Food \& Drug Insider Report, for example, revealed that eighty-four percent of respondents suppressed potentially legitimate complaints against the FDA for fear of retaliation. ${ }^{17}$ The whistle-blowing generic drug company, Barr Laboratories, filed suit against the FDA, claiming that the agency had retaliated against it for bringing corruption in the agency to light. ${ }^{18}$ These perceived problems triggered several days of hearings in 1995 by the House Commerce Subcommittee on Oversight and Investigations, which elicited testimony from inventors, patients, health care professionals, industry officials, and lawyers who asserted that the agency engages in abusive tactics such as threats of nonapproval and the improper use of seizure, inspection, and subpoena powers. ${ }^{19}$

The natural response to such alleged abusive tactics would be to bring suit against the agency, but such a response might not be in the best interests of the affected company. Assuming suit is filed and the affected company prevails, the company whose survival hinges on the agency's continued good graces, likely will lose in the long run. Moreover, the chances of winning are slim because, in such cases, the available checks

${ }^{15}$ One biotechnology company, for example, was forced to idle a new manufacturing facility and over 200 employees for 360 days after the FDA's initial plant inspection, to await the FDA's formal nod of approval. The same biotechnology company also was forced to idle an entire distribution facility for over three months while awaiting an FDA inspector to green light a new freezer. See Drugs \& Biologics: Hearings Before the Subcomm. on Oversight and Investigations of the House Comm. on Commerce, 104th Cong., 1st Sess. 19, 22 (1995) [hereinafter O\&I Hearings] (statement of Gordon Binder, Chairman and CEO, Amgen Corp.).

${ }^{16}$ See, e.g., FDA Panel Hears of Misuses of Power; Democrats Want Balanced Record, BNA HEALTH CARE DaILY, July 26, 1995, available in LEXIS, Health Library, BNAHCD File (summarizing testimony of witnesses before the House Commerce Subcomm. on Oversight and Investigations who experienced abusive tactics by the FDA); see also O\&I Hearings, supra note 15, at 138-46, 156-57 (testimony of Arthur $\mathbf{H}$. Kibbe, Prof. of Pharmaceutical Sciences, Wilkes Univ.).

${ }^{17}$ Peter Brimelow \& Leslie Spencer, Food \& Drugs \& Politics, Forbes, Nov. 22, 1993, at 115.

${ }^{18}$ Id. See also In re Barr Labs., Inc., 930 F.2d 72, 75 (D.C. Cir.), cert. denied, 502 U.S. 906 (1991); United States v. Barr Labs., Inc., 812 F. Supp. 458 (D.N.J. 1993).

${ }^{19}$ See generally O\&I Hearings, supra note 15. 
on agency abuse - Congress and the courts - face a debate between the regulated entity and the FDA over the facts and circumstances of the alleged abuse. Not surprisingly, neither Congress nor the courts are eager to second-guess an agency charged with consumer protection. Most likely, they will defer to agency expertise. ${ }^{20}$ Given the FDA's monopolistic position, an entity faced with such a situation has nowhere to turn. The FDA, in a very real and practical sense, can force a company to play by the agency's own rules.

\section{B. Institutional Risk Aversion}

Entities regulated by the FDA also face a zero-risk, "better safe than sorry" culture in which action (or inaction) is taken more out of fear of the unknown than respect and appreciation of the known. A certain degree of institutional risk aversion is understandable given that the FDA's historical mission has been to place consumer health above (and perhaps even to the exclusion of) all other considerations. The question for reformers, however, is not whether the FDA should continue to attach high value to consumer health and safety, but rather is what factors the agency should consider when attempting to achieve this important goal. When the costs of excessive caution are factored in - not only lost profits, jobs, and foregone research and development, but, more importantly, lost lives that could have benefited from products frozen in the FDA queue - the net effect to the American consumer arguably is negative, not positive. ${ }^{21}$ Indeed, a study by the Cato Institute, a conservative think-tank, estimates that the FDA's excessive caution in granting product approvals carries a stunning price tag of over 200,000 lost lives during the last thirty years. ${ }^{22}$ The Competitive Enterprise Institute estimates that the FDA's delay in approving the ulcer drug misoprostol resulted in 15,000 deaths, and its delay in approving streptokinase, a blood clot eliminator, resulted in 22,000 deaths. ${ }^{23}$ Another source estimates that the FDA's ten-year delay, from 1967 to

\footnotetext{
${ }^{20}$ For example, in a suit alleging improper denial of an NDA, the D.C. Circuit's one paragraph opinion read as follows:

We have examined the record of the administrative hearing on this point with care, particularly with a view to grasping as best we can the nature of the divergences between the differing expert witnesses. Although the matter seems to us one not entirely free from doubt, we remind ourselves that our role in the Congressional scheme is not to give an independent judgment of our own, but rather to determine whether the expert agency entrusted with regulatory responsibility has taken an irrational or arbitrary view of the evidence assembled before it. We are unable to say that it has; and, accordingly, the petition for review is denied.

Unimed, Inc. v. Richardson, 458 F.2d 787 (D.C. Cir. 1972). Professors Hutt and Merrill assert that "[n]o sponsor has successfully sought reversal of an FDA refusal to approve its drug. The lesson has not been lost on the vast majority of applicants who understand that the only way to secure approval of an NDA is to satisfy the agency." Peter Barton Hutt \& Richard A. Merrill, Food \& Drug Law: Cases and Materials 534 (2d ed. 1991).

${ }^{21}$ Id. (noting example of the hepatitis A vaccine). See also John Carey, et al., Is the FDA Hooked on Caution?, Bus. WEEK, Jan. 30, 1995, at 72. Analogously, the 1962 amendments to the Federal Food, Drug, and Cosmetic Act (Pub. L. No. 87-781, 76 Stat. 780 (1962)), which instituted, inter alia, premarket approval by the FDA for prescription drugs, was estimated in 1973 to result in over $\$ 450,000,000$ per year in gross therapeutic benefits lost due to a decline in available medical treatments to consumers. Regulation of Pharmaceutical Innovation, 1973: Hearings Before the Subcomm. on Monopoly of the Senate Comm. on Small Business, 93d Cong., 1st Sess. 9802, 9803-07 (1973) (remarks of economist Sam Peltzman).

${ }^{22}$ Daniel Green, Obstacle Course for Drug Producers: Pressure for Reform of the U.S. Food \& Drug Administration is Growing, FIN. TIMEs, Aug. 21, 1995, at 12.

${ }^{23}$ Mona Charen, Big Brother FDA, BALT. SUN, Jan. 3, 1995, at 11A; see also Sam Kazman, Deadly Overcaution: FDA's Drug Approval Process, 1 J. REg. \& Soc. Costs 35, $47-48$ (1990) (asserting that during FDA consideration of misoprostol, 8000 to 15,000 gastric ulcer patients died).
} 
1976, in approving certain beta-blocker drugs for the treatment of hypertension and cardiovascular disorders is cumulatively responsible for 100,000 preventable deaths. ${ }^{24}$ As pharmacologists William Wardell and Louis Lasagna observed in 1975:

The point is obvious. Introduction of a new drug that produced fatalities anywhere approaching this magnitude would be regarded as a major disaster, but the undoubted occurrence of deaths through failure to introduce a drug has so far gone unremarked. It would not take many examples [of drugs not approved by FDA] to show that earlier introduction of some new drugs might more than counterbalance all the new drug toxicity of the past decade. ${ }^{25}$

Given that the FDA's historical mission has been consumer protection, why has the FDA failed to see the other side of this equation? The most likely explanation is atmospherics. Congressional and media attention are triggered by failure, exacerbating the agency's tendency towards caution. Rarely, if ever, does Congress hold a hearing to praise the FDA for streamlining procedures or expeditiously approving new drugs or devices. ${ }^{26}$ Likewise, the media collectively yawns at expeditious approvals; if they are covered at all, they are relegated to the business section of the paper, presumably of interest only to those with an investment interest in the affected company. In short, it is only the horror stories that seem to catch the attention of Congress and the media, and hence, the public at large. When these horror stories come to light, members of Congress vilify the FDA as an agency that has acted too fast and accepted data too readily, all in reckless disregard of the health and safety of the impuissant consumer. Because people cannot see the deaths caused by FDA delays, the spotlight of public interest is never shone on those victims. Given the miasma of being damned if they do and ignored if they do not, it is little wonder that the FDA often simply "does not," and errs on the side of caution.

Historical factors also have played an important role in encouraging the FDA's preference for caution. The generic drug scandal of the late $1980 \mathrm{~s}^{27}$ heightened media and congressional scrutiny of the agency, and encouraged the FDA to adopt an even harsher attitude toward the industries it regulates. Furthermore, two laws passed in 1990 - the Nutrition Labeling and Education Act $^{28}$ and the Safe Medical Devices Act ${ }^{29}$ greatly expanded FDA authority over food labeling and medical devices without a corresponding significant increase in FDA resources. ${ }^{30}$ The result, predictably, is an agency

${ }^{24}$ See Brimelow \& Spencer, supra note 17 , at 115.

${ }^{25}$ William M. Wardell \& Louis lasagna, Regulation \& Drug Development 73 (1975).

${ }^{26}$ See Regulation of New Drug Research \& Development; Joint Hearings Before the Senate Comm. on Labor \& Public Welfare and the Subcomm. on Admin. Prac. and Proc. of the Senate Comm. on the Judiciary, 93d Cong., 2d Sess. (1974) (testimony of FDA Comm'r Alexander Schmidt, M.D.) ("In all of our history, we are unable to find one instance where a Congressional hearing investigated the failure of FDA to approve a new drug.... This can be remedied only by Congressional recognition that the failure to approve an important new drug may well be extremely detrimental to the public health.").

${ }^{27}$ Allegations by some generic drug manufacturers led to an extensive investigation by a House Oversight Subcommittee, which revealed that several FDA employees had accepted bribes from generic drug manufacturers in return for favorable and more expeditious review and that some generic manufacturers had falsified data to garner FDA approval. See generally FDA's Generic Drug Approval Process (Parts 13), supra note 2 .

${ }^{28}$ Pub. L. No. 101-535, 104 Stat. 2353 (1990).

${ }^{29}$ Pub. L. No. 101-629, 104 Stat. 4511 (1990).

${ }^{30}$ While FDA appropriations were increased from $\$ 568.7$ million in fiscal year 1990 , see Trade \& Gov't Memos, F-D-C REP.("The Pink Sheet"), Nov. 20, 1989, available in LEXIS, Health Library, FDC File, to $\$ 656.5$ million in fiscal year 1991, see Trade \& Gov't Memos, F-D-C REP. ("The Pink Sheet"), Oct. 29, 
under increased pressure to do more with less, creating more delay with less industry and consumer satisfaction.

The FDA's institutional risk aversion often means that reviewers will order companies to conduct more costly, duplicative, and time-consuming tests. New drugs take an average of 8.5 years from clinical testing to FDA approval, at a total research and development cost of almost $\$ 300,000,000 .{ }^{31}$ While the FDA's review time has declined in recent years, ${ }^{32}$ these gains have been offset by a significant increase in the overall length of time required to garner FDA approval as measured from the time of chemical synthesis, due in substantial part to the FDA's demands for more numerous and complex preclinical and clinical tests. ${ }^{33}$ For example, the breakthrough vaccine for chickenpox, Varivax, finally obtained approval in 1995 after fifteen years, even though the drug had been tested on over 10,000 subjects and enjoyed the approval of European regulatory agencies during most of this period. ${ }^{34}$ In late 1994, the FDA approved a long-awaited oral diabetes medication, metformin, which had been widely and successfully used in Europe and Canada for over thirty-five years. ${ }^{35}$

The FDA's review deficiency, moreover, is not limited to drugs. The time necessary to garner FDA approval for a new medical device has risen to an average of over two years, ${ }^{36}$ at a cost of about $\$ 75,000,000 .{ }^{37}$ The average time for FDA approval of food additives is currently over twenty months, with almost 300 food additive petitions backlogged, some of which have been awaiting decision for over twenty years. ${ }^{38}$ Indeed, only five new direct human food additives have been approved by the FDA in the last twenty-five years, leading one expert to proclaim that " $t]$ he food additive approval process in America is dead. It has been killed by the FDA. No food company of which I am aware would even consider beginning research today on a new food additive." ${ }^{39}$

For truly innovative products, the delays are even worse; often the FDA does not know how to assess their safety and efficacy, and therefore does not act at all. For

1990 , available in LEXIS, Health Library, FDC File, this represents only a $15.4 \%$ pre-inflation increase, hardly sufficient to offset the significant expansion in FDA responsibility created by these two new laws. Likewise, appropriations for fiscal year 1992 increased only $15.8 \%$ pre-inflation, to $\$ 759.9$ million. See Industry \& Washington Memos, M-D-D-I ReP. ("The Gray Sheet"), Oct. 7, 1991, available in LEXIS, Health Library, FDC File.

${ }^{31}$ See O\&I Hearings, supra note 15, at 131 (written testimony of Kenneth Kaitin, Ph.D., Assoc. Dir., Tufts Center for the Study of Drug Development). A recent study conducted by the Office of Technology Assessment places the average drug development cost even higher, at $\$ 400,000,000$ in 1994 dollars. Id.

${ }^{32}$ See generally General ACCOUNTING OfFICE, supra note 6; see also O\&I Hearings, supra note 15, at 50 (statement of William Schultz, Deputy Comm'r for Policy, FDA).

${ }^{33}$ O\&I Hearings, supra note 15, at 132 (written testimony of Kenneth Kaitin, Ph.D., Assoc. Dir., Tufts Center for the Study of Drug Development). The overall increase in total time from chemical synthesis to FDA approval from 1963-1965 (the years immediately following passage of the 1962 Drug Amendments, which provided the FDA with authority to require premarket approval of new drugs) to 1991-1993 was $156 \% . I d$.

${ }^{34}$ Green, supra note 22, at 12; see also Carey et al., supra note 21, at 72 .

${ }^{35}$ Sally Squires, New Drug Approved for Type II Diabetics: Metformin Said to Fill "Some Very Important Gaps in Therapeutic Strategies," WASH. PoST, May 16, 1995, at Z7.

${ }^{36}$ In 1993, the most recent year for which complete data is available, the General Accounting Office found that the median review time for original PMA applications for new medical devices was approximately 800 days. See General Accounting Office, supra note 7, at 8; see also id. at 7 (stating that the median time between submission of an application for a PMA of a new medical device ranged from 414 days in 1989 to 984 days in 1992).

${ }^{37}$ Carey et al., supra note 21 , at 72.

${ }^{38}$ See Food Additive Hearing, supra note 3, at 6.

${ }^{39}$ Peter Barton Hutt, Remarks at the Annual Meeting of the Institute of Food Technologists 18, 20 (June 5, 1995) (transcript on file with author). The five approved food additives are TBHQ (1972), Aspartame (1981), Polydextrose (1981), Acesulfame K (1988), and Gellan Gum (1990). Id. at 18. 
example, the innovative fat substitute, olestra, finally was approved by the FDA in January $1996,{ }^{40}$ after twenty-one years of FDA indecision, the provision of over 100,000 pages of research data, and development costs of well over $\$ 300,000,000 .^{41}$ Faced with this magnitude of risk aversion by the FDA, manufacturers have little incentive to invest in costly research and development for innovative products. The loser arguably is the American consumer, who has fewer potentially beneficial, or even life-saving, alternatives from which to choose.

The FDA's slow review process may impact negatively not only consumers, but also American companies' ability to compete globally. Between 1986 and 1991, there was a "drug lag" of 4.1 years between the time a drug received approval by a European authority and the time the FDA granted approval ${ }^{42}$ While Commissioner Kessler claims that the drug lag "is today a myth" 43 and that FDA review times recently have declined due to the passage of a user fee law in 1992, the total development time for a new drug in the United States is still significantly greater than in Europe. The increased development time is due in large part to the increased magnitude and complexity of the clinical trials required by the FDA. For example, the number of clinical trials required per NDA doubled from 1977 to 1992 , the number of subjects per NDA tripled from 1981 to 1992 , and the number of procedures per subject similarly exploded. ${ }^{44}$

Thus, when measured in terms of the total development time imposed by regulation - not just raw review time - there is still a significant drug lag. This lag has created a virtual exodus to Europe of some of the most competitive industries, and their accompanying capital investment and high paying jobs. A 1994 survey by the Pharmaceutical Research and Manufacturers of America (then the Pharmaceutical Manufacturers' Association), for example, revealed that most pharmaceutical companies now opt to conduct Phase I clinical trials in Europe rather than the United States because of the significant difference in the amount of paperwork required by the FDA: over 2000 pages of data versus approximately forty pages in Europe..$^{45}$

The drug lag has cost the United States not only the opportunity to be the primary

40 See New Fat Substitute Approved by FDA, FiN. Times, Jan. 25, 1996, at 3. The FDA approval requires that all products which contain olestra affix the following warning:

This product contains olestra. Olestra may cause abdominal cramping and loose stools. Olestra inhibits the absorption of some vitamins and other nutrients. Vitamins A, D, E \& K have been added.

Id. The FDA also is requiring Procter \& Gamble to conduct post-approval monitoring studies and will reassess its decision in 30 months. Id. The FDA's conditions on the approval of olestra are based on the concerns expressed by some scientists that overconsumption of olestra may cause anal leakage and depletion of important nutrients. See Lori Valigra, Harvard Scientists Warn About P\&G's Olestra Fake Fat, Reuter Eur. Bus. Rep., Jan. 18, 1996, at 1.

${ }^{41}$ Procter \& Gamble filed its investigational new drug (IND) application with the FDA in 1975. See Jennifer Lawrence, Whatever Happened to Olestra: How P\&G's Hopes for Food Division's Future Got Mired in FDA Quicksand, ADVERTISING AGE, May 2, 1994, at 16, 17.

${ }^{12}$ See O\&I Hearings, supra note 15, at 7 (statement of Congressman Cox).

${ }^{43}$ See Transcript No. 217-11, CNN News, Dec. 13, 1995, available in LEXIS, NEXIS Library, Curnws File; David A. Kessler, Remarks by the Commissioner of Food and Drugs, 51 Food \& Drug L.J. 207, 208 (1996).

${ }^{44}$ In the period from 1977 to 1980 the average number of clinical trials per NDA was 30 , but by 1989 to 1992 the average number of clinical trials per NDA had ballooned to 60. O\&I Hearings, supra note 15, at 132 (statement of Kenneth Kaitin, Ph.D., Assoc. Dir., Tufts Center for the Study of Drug Development). The number of subjects per NDA increased from 1300 (in the 1981 to 1984 period) to 3600 (in the 1989 to 1992 period), and the number of procedures per subject increased from 51 to 86 in Phase I, from 47 to 109 in Phase II, and from 42 to 62 in Phase III. Id.

${ }^{45}$ See O\& I Hearings, supra note 15, at 4-5 (written statement of George B. Rathmann, Ph.D., Chairman \& CEO, ICOS Corp.). 
situs for valuable research and testing of new drugs, but it also has cost U.S. consumers untold losses by decreasing their ability to select among beneficial therapeutic alternatives. A 1995 study by the Tufts Center for the Study of Drug Development concluded that from 1987 to 1992 seventy-three percent of drugs approved by the FDA had been approved earlier by foreign governmental agencies. ${ }^{46}$ Indeed, twenty-seven percent of the drugs approved by the FDA during this period had been available to consumers elsewhere for six years or more. ${ }^{47}$ As a result, many critically ill Americans have been forced to travel to foreign countries in search of beneficial, cutting-edge therapies not yet approved in the United States. One migraine sufferer, for example, told a congressional subcommittee that she repeatedly had to travel to Canada for over two years to receive the breakthrough drug sumatripan. ${ }^{48}$ An economist at the University of California-Davis, told reporters that his aging mother, who had been diagnosed with liver cancer, traveled to Japan to receive beneficial chemotherapy treatments not yet approved by the FDA. ${ }^{49}$ Even the physician-inventor of an artificial shoulder implant cannot yet obtain his own device to abate his arthritis pain, despite the fact that the device has been widely used in Europe, Australia, and Latin America for several years. ${ }^{50}$

The specter of the loss of global competitiveness is nowhere more feared than by the fledgling American biotechnology industry, ${ }^{51}$ which is comprised mostly of smallto-mid-sized businesses with an average flame-out capitalization of only twenty-five months. ${ }^{52}$ Biotechnology firms with limited financial resources often cannot afford to wait on FDA decisionmaking in the same way that better capitalized pharmaceutical companies can; FDA decisions that take longer than two years may come too late for them. This should be cause for concern because, although the American biotechnology industry is only in its incipiency, it holds the potential to become one of America's most competitive, job-producing, export-oriented industries of the twenty-first century. Thus far, American biotechnology firms have dominated the global biotechnology marketplace: of thirty-six biotechnology human drugs and vaccines approved for use in the United States, Europe, and Japan through June 1992, fifty-eight percent were developed in America. ${ }^{53}$ Faced with an industry-wide $\$ 11$ billion loss over the last three years, excessive agency delay may retard the growth or viability of the American biotechnology industry. ${ }^{54}$

Such negative effects already are being felt. For example, although the United States is most often the site for discovery of new biotechnology drugs, it is not often the site for clinical testing or initial market approval: only forty-seven percent of first clinical trials and eighteen percent of first market approvals for biotechnology drugs occurred in the United States. ${ }^{55}$ The result is much the same as that for nonbiotechnology drugs:

${ }^{46}$ See id. at 134 (written statement of Kenneth Kaitin, Ph.D., Assoc. Dir., Tufts Center for the Study of Drug Development).

${ }^{47}$ Id.

${ }^{48}$ See id. at 25-26 (testimony of Pamela Conford, Exec. Dir., Epilepsy Institute).

${ }^{49}$ See Brimelow \& Spencer, supra note 17 , at 115.

${ }^{50}$ See C. Ray Holman, U.S. Lags in Approval of Health Products, St. Louis Post-Dispatch, May 14, 1996, at 11B. Ironically, the device is the most popularly used device of its kind in Australia, Finland, and Spain. Id.

${ }^{51}$ Biotechnology uses living organisms such as cells and viruses, and naturally-occurring substances such as proteins, enzymes, and antibodies to create medicines that fight disease and infection.

${ }^{32}$ See O\&I Hearings, supra note 15, at 21 (testimony of Gordon Binder, Chairman \& CEO, Amgen Corp.).

${ }^{53}$ Id. at 20.

${ }^{54}$ See id. at 21 .

ss Id. at 135 (written statement of Kenneth Kaitin, Ph.D., Assoc. Dir., Tufts Center for the Study of Drug Development). 
loss of jobs, loss of lives, and an exodus of desperately ill Americans to foreign shores. Finding a way to speed biotechnology product review without compromising safety standards and without appearing to favor biotechnology firms over other regulated industries will be extremely difficult in the current monopolistic environment. Privatization of the review process for all products regulated by the FDA, by contrast, potentially could speed review, maintain current safety standards, and yet not appear to play favorites among regulated industries.

\section{Political Atmospherics}

The FDA's monopolistic position and its general preference for caution have existed for years. Thus, the current zeal to reform the FDA likely emanates from political, not just substantive, sources. In politics, as in life, timing is everything: the same complaints that fell on deaf ears just a few years ago have found a sympathetic ear in the new Republican Congress. Antipathy toward the FDA first surfaced in the 1994 passage of the Dietary Supplement Health and Education Act (DSHEA), ${ }^{56}$ which essentially eviscerated the FDA's authority to regulate dietary supplements. Interestingly, DSHEA was passed by the Democratically controlled 103d Congress by unanimous consent, indicating that the desire to scale back FDA authority has deeper bi-partisan roots than generally perceived. Another blow came in the fiscal year 1996 appropriations bill ${ }^{57}$ passed by Congress, which revoked a $\$ 228,000,000$ fund, initially authorized by a Democratic-controlled Congress, that would have enabled the FDA to consolidate its myriad offices scattered throughout metropolitan Washington, D.C. ${ }^{58}$

Emboldened by the new political climate, the votaries of reform and their substantial political action committees (PACs) ${ }^{59}$ have launched a well-heeled, well-organized public relations blitzkrieg. A Gingrich-backed think-tank, the Progress and Freedom Foundation, has raised over $\$ 400,000$ from FDA-regulated companies ${ }^{60}$ to launch an ambitious project entitled "Medical Innovation and Personal Health in the 21 st Century," aimed at dismantling the FDA and devising an alternative, purely private method of product approval. Citizens for a Sound Economy, a conservative group headed by former Bush Administration White House Counsel, C. Boyden Gray, likewise has added its voice to the call for FDA privatization. ${ }^{61}$ In addition, a formerly unknown group, the Washington Legal Foundation (WLF), plunged headfirst into the debate by taking out expensive full-page advertisements in virtually every publication likely to be read by

${ }^{56}$ Pub. L. No. 103-417, 108 Stat. 4325 (1994).

s7 Pub. L. No. 104-37, 109 Stat. 299 (1995).

58 See Daniel Greenberg, Blueprints for Shrinking the Government: Republican Proposals for Government Cost Cuts Affect Health Care Allocations, LANCET, May 20, 1995, at 1295. Interestingly, reports have surfaced that congressional Republicans may seek to cut a deal with the FDA and the Clinton Administration whereby funds for a new FDA campus may be freed if the Administration agrees to support FDA reform legislation. See FDA Reforms: Will FDA Get New Site if it Backs Reform Bills? MED. DEvicE APPROVAL LeTtER, June 1, 1996, available in LEXIS, NEXIS Library, Nwltrs File.

${ }^{59} \mathrm{~A}$ review of some of the leading drug and food company PACs revealed an astounding level of contributions during the 1993-1994 cycle. The author randomly selected 15 drug-related PACs and six food-related PACs with which the author was familiar, and discovered that the 15 drug PACs contributed $\$ 1,602,478$, and the six food PACs contributed $\$ 946,326$ - a grand total of $\$ 2,548,804$. When this total is divided by the number of Congressmen and Senators (535), it reveals that these 21 PACs alone contributed an average of $\$ 4764$ per member of Congress.

${ }^{50}$ Peter Stone, The Demolition Prescription: Industry Leaders and Lawmakers Want to Overhaul the Food \& Drug Administration, Orlando Sentinel, Mar. 26, 1995, at G1.

${ }^{61}$ See FDA Reform Pledged "This Congress," MarketLetter, Feb. 13, 1995, at 1. 
policymakers: the New York Times, USA Today, The Wall Street Journal, The National Journal, and the ubiquitous Capitol Hill newspaper, Roll Call. ${ }^{62}$ The advertisements contained a picture of two gravestones accompanied by a headline that proclaimed, "If a Murderer Kills You, It's Homicide. If a Drunk Driver Kills You, It's Manslaughter. If the FDA Kills You, It's Just Being Cautious." ${ }^{63}$ The WLF's aggressive advertising campaign caught the attention of Congress and, perhaps adumbrating the reform efforts to come, a top WLF executive, Alan Slobodin, was hired as counsel to the House Committee on Commerce shortly after the advertisements were published. ${ }^{64}$

Faced with this impressive army of reformers and sensing the political weathervane turning, the Clinton Administration has joined the call for legislative and regulatory changes in the FDA as part of its "Reinventing Government" initiative. ${ }^{65}$ Thus, the full spectrum of political actors appear to agree that some degree of privatization of the FDA review process is desirable. The next section, therefore, explores the spectrum of reform proposals that are likely to be considered.

\section{ReForm Proposals}

Privatization of the FDA's review function could occur in one of two ways: (1) statutorily, by an act of Congress; or (2) administratively, by regulations issued by the FDA. Both routes to reform already have been proposed.

\section{A. Legislative Reform Proposals}

With both House Speaker Newt Gingrich and Energy and Commerce Committee Chairman Thomas J. Bliley, Jr. (R-Va.) indicating that FDA reform is a legislative priority, ${ }^{66}$ it is not surprising that several comprehensive FDA reform bills have been introduced by influential legislators on both sides of the political aisle. Some proposals are simply too radical to be politically palatable and therefore will not be discussed at length here. The conservative Competitive Enterprise Institute, for example, advocates the elimination of statutory standards for safety and efficacy altogether, leaving these matters to be resolved by the free market. ${ }^{67} \mathrm{~A}$ less radical approach - the primary focus of this article - would permit private entities to compete with the FDA for certain portions of the review process. This concept appears to enjoy broad, bipartisan support, although there are widely divergent opinions as to the proper parameters of

\footnotetext{
2 William G. Castagnoli, What is the WLF and Why is it Challenging the FDA?, Med. Marketing \& Media, Apr. 1995, at 26.

${ }^{63}$ Id. See also Should Congress Curb the FDA's Power over Drugs, Vitamins, and Medical Devices?. HeALTh, May 1995, at 34 (containing dialectic between WLF and Public Citizen). While the advertisements created a lot of interest in FDA reform, they also prompted many to wonder who the WLF was and where it obtained its money. WLF is a nonprofit organization committed to probusiness issues, and is funded and directed by numerous conservative legal academicians and prestigious law firms. It also has been linked to the Progress and Freedom Foundation, the conservative think-tank closely aligned with House Speaker Newt Gingrich. See Philip J. Hilts, FDA Becomes Target of Empowered Group, N.Y. TIMEs, Feb. 12, 1995, at 24 .

${ }^{64}$ Castagnoli, supra note 62 , at 26.

os See generally National Performance Review, supra note 1; see also Drug \& Administration Promotes FDA Reforms; Members Accuse Agency of Intimidation, HeAlTH Leg. \& REg., Apr. 12, 1995, available in LEXIS, NEXIS Library, Nwitrs File.

${ }^{66}$ FDA/Environmental Bills to be Discussed "In Parallel": Gingrich, Med. Device Approval LeTTER, Nov. 1, 1995, available in LEXIS, NEXIS Library, Nwltrs File.

${ }^{67}$ See Hilts, supra note 63 , at 24.
} 
privatization.

The first privatization proposal, introduced on April 4, 1995, ${ }^{68}$ was sponsored by Congressman Ron Wyden (D-Or.), the ranking minority member of the House Commerce Subcommittee on Oversight and Investigations, ${ }^{69}$ which has oversight jurisdiction of the FDA. Wyden's bill would carve out limited areas for domestic third parties to review drugs, biologics, and medical devices (but not food additives) in several ways. First, the bill would permit institutional review boards (IRBs) to approve applications for investigational new drugs or devices. ${ }^{70}$ The FDA would retain authority to veto an IRB's decision during the first thirty days after the submission of the IRB-approved application; failure to act within this thirty-day period would result in a deemed approval of the drug or device. ${ }^{71}$ Second, Wyden's bill would permit the FDA to contract with private entities to conduct indépendent testing such as toxicology reviews, and chemical and statistical analyses. ${ }^{72}$ Third, the bill would permit any applicant for a new drug or biological product that treats a serious or life-threatening condition to request that the application be reviewed by an expert advisory panel appointed by the Secretary of the Department of Health and Human Services (DHHS) and comprised of medical and scientific experts. ${ }^{73}$ If the expert panel recommended approval, the drug or biological product would be deemed approved unless the FDA determined, within forty-five days of receiving the recommendation, that the applicant had not met the statutory standards. $^{74}$

The Wyden bill's dose of competition is limited. The bill, however, is significant in two respects. First, Wyden is a moderate Democrat and historically a staunch defender of the FDA. Thus, Wyden's recognition that the agency needs an injection of competition indicates that privatization enjoys support beyond the conservative Republican camp. Second, on a strategic level, Wyden's reputation as a respected Democratic player on health issues may mean that his bill will undercut the viability of more modest reform proposals likely to be favored by consumer groups and liberal Democrats such as former Commerce Committee Chairman John Dingell (D-Mich.) and former Commerce Health Subcommittee Chairman Henry Waxman (D-Cal.).$^{75}$ Thus, the Wyden proposal may well mark the Democratic position, rendering it likely that any reform ultimately agreed to will contain a significant dose of privatization.

Wyden's election to the U.S. Senate in January 1996 created a temporary vacuum in House leadership on the issue of FDA reform. The House Republicans moved quickly to fill the vacuum by creating a Republican Task Force on FDA Reform, chaired by

${ }^{68}$ H.R. 1742, 104th Cong., 1st Sess. (1995).

${ }^{69}$ On January 30, 1996, Congressman Wyden was elected to the U.S. Senate to fill the seat vacated by Senator Bob Packwood. Thus, the Wyden proposal no longer has a House sponsor, although it is expected that another Democratic member of the House will sponsor similar legislation that incorporates most, if not all, of the Wyden proposal.

${ }^{70}$ H.R. 1742 , supra note $68, \S 5$.

"Id.

Id. $\S 6(\mathrm{a})$.

${ }^{73} I d . \S 8$.

${ }^{74} \mathrm{Id}$. The expert panel would have 60 days from the date of the application submission to complete its review and recommend approval or disapproval to the FDA. Id.

's See Rep. Greenwood Pressing for FDA Reform: Legislation Mark-up Next Week by House Commerce/Health \& Environment Subcommittee, HeALtH NEws DalLy, June 19, 1996, at 4 (noting that Waxman has supported moderate reform and quoting staffer views of Democratic concerns with reform); Congressman Dingell Pushes for Bi-Partisan Effort to Halt Retaliation by FDA, BIOMEdICAL MARKET NEwSLETTER, July 1995, available in LEXIS, NEXIS Library, News File, Nwltrs Subfile (summarizing FDA reforms supported by Representative Dingell). 
Representative Jim Greenwood (R-Pa.). Extensive deliberations by the Task Force culminated in the March 29, 1996, introduction of three separate bills that tackle discrete areas of FDA reform: (1) drugs and biological products, ${ }^{76}(2)$ foods and animal drugs, ${ }^{77}$ and (3) medical devices. ${ }^{78}$ All three bills carve out a broad role for privatization; they would permit regulated entities to contract with private accredited review organizations of their choosing, whose recommendation would be deemed to be approved by the FDA unless the agency determines that there is a "reasonable probability" that the drug, medical device, or food additive is not safe or effective. ${ }^{79}$

On the Senate side of Capitol Hill, a bill introduced on December 13, 1995, by Senate Labor and Human Resources Committee Chairwoman Nancy Kassebaum (RKan.) ${ }^{80}$ was reported out of committee on March 28,1996 , by a bipartisan vote of twelve to four. ${ }^{81}$ The Kassebaum proposal has emerged as the moderate proposal, staking out a position somewhere between the more modest Wyden proposal and the more ambitious House Task Force triumvirate. The Kassebaum proposal mandates the availability of third-party review for all new product applications, but only if the FDA cannot complete at least ninety-five percent of its reviews for the relevant product category within specified statutory deadlines. ${ }^{82}$ If the private reviewing entity recommends approval, the application will be deemed approved unless, within thirty days of receipt of the recommendation, the FDA publishes a notice in the Federal Register setting forth its reasons for disagreeing with the private reviewer. ${ }^{83}$

The Kassebaum proposal essentially uses the threat of private review to give teeth to statutory review deadlines. But it also goes one step further in its attempt to inject competition into the FDA's review market: it establishes deemed approval status of any new drug, biological product, device, food additive, or new animal drug that has been approved by the European Agency for the Evaluation of Medicinal Products (EMEA) or the United Kingdom's (UK's) Committee on Safety of Medicines (CSM) ${ }^{84}$ If the FDA has not acted affirmatively to disapprove a drug within thirty days of the statutory deadline for completion of its review process, an applicant that has obtained approval from the EMEA or CSM may obtain, upon request, deemed approval status. ${ }^{85}$

The Kassebaum bill uses a carrot-and-stick approach to privatization. If the FDA fails to act within a statutorily specified deadline for acting on an application, the applicant may either (1) petition the FDA for deemed status on the basis of EMEA or CSM approval, or (2) force review by a third party if the FDA has failed to meet the ninetyfive percent target for timely review. Significantly, however, if the FDA succeeds in acting upon applications within the statutory deadlines, it may enjoy the "carrot" of continued monopolization of the review process. Thus, the Kassebaum approach essentially gives the FDA a "first right of refusal" over application review by permitting it to

\footnotetext{
${ }^{76}$ H.R. 3199, 104th Cong., 2d Sess. (1996) (sponsored by Rep. Richard Burr (R-N.C.)).

${ }^{77}$ H.R. 3200, 104th Cong., 2d Sess. (1996) (sponsored by Rep. Scott Klug (R-Wis.)).

${ }^{78}$ H.R. 3201, 104th Cong., 2d Sess. (1996) (sponsored by Rep. Joe Barton (R-Tex.)).

${ }^{79}$ See H.R. 3199, supra note 76, § 7; H.R. 3200, supra note 77, § 105; H.R. 3201, supra note 78, $§ 11$.

${ }^{80}$ S. 1477, 104th Cong., 1st Sess. (1995). The Labor and Human Resources Committee is the Senate committee with jurisdiction over the FDA.

${ }^{81}$ See Christina Kent, Controversial FDA Overhaul Advances in Congress: Several Bills in Preparation, AM. MEd. News, Apr. 22, 1996, at 3. The bill reported out of the Labor and Human Resources Committee was in the nature of a substitute to the original $\mathrm{S}$. 1477, but the privatization approach of the original bill remained intact.

${ }^{82}$ S. 1477 , supra note 80, § 404.

${ }^{83}$ Id.

${ }^{84} \mathrm{Id}$.

${ }^{85} \mathrm{Id}$.
} 
retain its monopolistic position if it acts swiftly enough. If the agency fails to meet its deadlines, however, the barriers to entry in the review market are lifted; the monopoly crumbles; and competitors such as CSM, EMEA, and domestic third-party reviewers enter the market.

Two distinct sources of private competition emerge from the House and Senate proposals: domestic and foreign. Within the category of domestic competition, there are two different approaches: (1) direct private contracting and (2) indirect private contracting. Direct contracting would permit a regulated entity to select and pay a private domestic reviewer directly. Indirect contracting, on the other hand, would permit contracting with private reviewers, but only if the government (i.e., the FDA) selects and pays the private reviewer. The House Task Force bills take the first approach (direct contracting), while the Kassebaum bill takes the latter (indirect contracting). The House and Senate bills differ not only with regard to the manner of private contracting (i.e., direct versus indirect), but also with regard to the availability thereof. The House Task Force proposals, for example, permit regulated entities to enter into direct contracts with accredited private reviewers at any time. The Kassebaum proposal, by contrast, permits the use of indirect contracts only if the FDA fails to meet certain statutory goals for the completion of product reviews.

With regard to foreign competition, the Kassebaum proposal would grant deemed approval status in the United States for drugs, biological products, devices, or food additives that "ha[ve] met the marketing requirements of the European Union or the United Kingdom[,]" if the FDA failed to act within a specified time frame. ${ }^{86}$ The Wyden and Republican Task Force proposals, by contrast, contain no provision to recognize the legitimacy of foreign approval. ${ }^{87}$

\section{B. FDA Reform Proposals}

In an effort perhaps to head off congressional reform efforts, in the summer and fall of 1995 the FDA announced that it was initiating a series of regulatory reforms aimed at enhancing efficiency. ${ }^{88}$ Specifically, the FDA has proposed a limited pilot project to gather information on the feasibility of third-party review of medical devices. ${ }^{89}$ Under this pilot project, the FDA will select domestic third parties to review premarket notifications $^{90}$ for Class I and II devices ${ }^{91}$ that present a low-to-moderate risk to patients. ${ }^{92}$

${ }^{8} I$ Id.

87 The House Republican Task Force proposals, however, require the Secretary of DHHS to "seek appropriate reciprocal arrangements" with other countries that may be construed to permit the FDA to institute mutual recognition of foreign approvals on its own initiative. See H.R. 3199, supra note 76, § 19; H.R. 3200, supra note 77, §109; H.R. 3201, supra note 78, §16.

${ }^{88}$ Some of the proposed reforms include: reducing the number of minor manufacturing and manufacturing supplement changes that require FDA prior approval, permitting biotechnology companies to use small-scale pilot facilities for manufacturing products that have not yet received FDA approval, reducing the number of NDAs that require environmental impact assessments, deleting the requirement of batch-bybatch certification for insulin and antibiotics, and reducing administrative burdens (such as labeling requirements) on the export of drugs to other countries. See generally National Performance Review, supra note 1; see also O\&I Hearings, supra note 15, at 51-52 (statement of William Schultz, Deputy Comm' $r$ for Pol'y, FDA).

${ }_{89}^{60}$ Fed. Reg. 28,618 (June 1,1995).

${ }^{90}$ PMNs are required under section 510(k) of the Federal Food, Drug, and Cosmetic Act (FDCA) for devices deemed to be "substantially equivalent" to certain grandfathered devices as set forth in sections $513(f)(1)$ and $515(b)(1)$ of the Act. See 21 U.S.C. $\$ \S 360(k), 360$ c(f)(1), 360e(b)(1).

${ }^{91}$ Class I devices are those for which no safety standard or premarket approval is required because the general adulteration and misbranding provisions of the FDCA are adequate to ensure safety. Examples of 
Devices that require the submission of clinical data will be excluded from the pilot. ${ }^{93}$ Third-party reviewers will be selected by the FDA on the basis of compliance with specified credentials such as personnel training and expertise and strict protections against conflicts of interest. ${ }^{94}$ Premarket notification applicants who wish to have their device applications reviewed by the private reviewer will have to pay a user fee, which will be negotiated privately between the third-party reviewer and the device applicant. ${ }^{95}$

Critics of the agency contend that the FDA's last-minute critical self-examination is too little, too late. They believe that the FDA is hostile to privatization, viewing it as a threat to the agency's future, providing no assurance that the agency will not return to its old ways once the political pressure is removed. For example, one of the FDA's proposed reforms is to delete the onerous requirement that insulin and antibiotics receive batch-by-batch certification. ${ }^{96}$ While the FDA boasts that this reform will remove over 700 pages from the Code of Federal Regulations, ${ }^{97}$ critics wonder why it was so long in coming, especially when a Citizens" Advisory Committee "questioned the advisability" of the batch-by-batch certification procedure as early as $1962 . .^{98}$

Moreover, the FDA's decision to limit the pilot project to include only certain lowto-moderate risk medical devices seems illogical given that the products not covered such as food additives and prescription drugs - arguably are the products most affected by the FDA's review monopolization. ${ }^{99}$ Perhaps the agency opted to limit the project based on a concern that privatizing review for drugs or food additives would be riskier than for medical devices. Yet, if risk is the reason for the limited scope of the pilot, the proper course would be to include all products that present only a low-tomoderate risk to patients. Perhaps the FDA is concerned that there would not be any entities qualified to conduct private drug or food additive reviews. If this is the case, however, the proper course of action would be to deny certification to reviewers that do not conform to the FDA's participation standards rather than limiting the pilot to medical devices.

Confining the scope of the pilot to medical devices also has significant shortcomings in terms of empirical research value. The project, by definition, will not yield any data regarding the feasibility of privatizing drug or food additive reviews, leaving an empirical void in a large segment of the FDA's review monopoly for at least the next two years. Moreover, the FDA's decision to limit the pilot to medical devices may doom

Class I devices are tongue depressors, stethoscopes, and gauze. See 21 U.S.C. $\$ 360$ c(a)(1)(A). Class II devices are those for which performance standards are required to ensure their safe use. An example of a Class II device is an infant incubator. See 21 U.S.C. $\$ 360$ c(a)(1)(B). Class III devices - which are not subject to the FDA's pilot project - are life-supporting, life-sustaining, or present a potential for unreasonable risk of illness or injury, and must obtain premarket approval from the FDA before they may be sold to consumers. See 21 U.S.C. $\S 360 \mathrm{c}(\mathrm{a})(1)(\mathrm{C})$. Examples of Class III devices include pacemakers and artificial heart valves.

9260 Fed. Reg. at 28,618 .

${ }^{93}$ Id. at $28,618-19$.

94 Id. at 28,619 .

${ }^{95}$ Id. Because the FDA medical device pilot permits the device applicant to pay the private reviewer directly, it is more akin to the direct contracting approach of the House Task Force proposals.

${ }^{96}$ See National Performance Review, supra note 1, at 12-13; see also O\&I Hearings, supra note 15, at 51 (statement of William Schultz, Deputy Comm'r for Pol'y, FDA).

${ }^{97}$ Id. See generally 21 C.F.R. pts. $429-460$ (1996).

98 Report of the Second Citizens Advisory Comm. on the Food \& Drug Admin. to the Secretary of Health, Education \& Welfare 35 (1962).

${ }^{99}$ See generally Food Additive Hearing, supra note 3; Wayne Koberstein, Inside FDA: Looking for Calm in the Eye of the Storm, Pharmaceutical Exec., Dec. 1995, at 36. 
it to failure because the adamant opposition of the medical device industry to the imposition of user fees ${ }^{100}$ will make it unlikely that many device manufacturers - particularly the small-to-medium sized manufacturers - will opt to participate.

Another potential problem with the scope of the pilot is its temporal span. Specifically, the pilot is slated to expire after two years, ${ }^{101}$ after which time the FDA would not be obligated to continue third-party review of devices if the agency did not like the results. Thus, two years down the line, after Congress has moved on to greener political pastures, the pilot project - even if objectively successful -- could be discontinued by the agency, and the concept of privatization could die a quiet, unnoticed death. While the idea of a temporally limited demonstration project may hold some appeal to those who are uneasy about privatization, permitting the FDA to select private reviewers according to its criteria and to end such a demonstration project sua sponte without so much as having to provide a report to Congress seems inherently suspicious. If a limited test run of the feasibility of private review is desired, the authorization perhaps should emanate from Congress rather than the FDA, because congressional members and their staffs likely would have greater incentive to monitor the privatization project and ensure that it is designed and implemented fairly. ${ }^{102}$

\section{The Desirability and ImPact of Privatization}

\section{A. The Benefits of Privatization}

Assuming that statutory reform authorizing privatization occurs, what would this "Brave New World" look like? What role would the FDA play? How would consumer protection be affected? Would privatization eliminate the backlogs and possible abuses of power? As an initial matter, it should be pointed out that the shibboleth "privatization" is potentially misleading. There are, in fact, two types of possible third-party reviewers, one of which is not "private" at all: (1) public, foreign governmental reviewers; and (2) private, domestic reviewers. Perhaps the most immediate and noticeable effect of privatization, under either domestic or foreign review, would be a liberation of FDA resources, enabling the agency to focus on other areas such as providing unbiased information to consumers, setting safety and efficacy standards, enforcing those standards. and, perhaps most important, determining when to exercise its veto power over thirdparty review recommendations. ${ }^{103} \mathrm{~A}$ post-privatization FDA thus would not be a mere

${ }^{100}$ HIMA Turns Thumbs Down on User Fees, Health Industry Today, May 1995, at 1. But see Device Industry Will Not Support FDA Plans to Collect User Fees, BNA Health CARE DaiLy, Mar. 6, 1995, at 1 (stating that the Board of Directors of the Health Industry Manufacturers Association (HIMA) favors user fees, but only if paid to private reviewers). Given the medical device industry's historically strong opposition to user fees, the HIMA Board's formal support of user fees to fund private review simply may indicate a preference for privatization-plus-user-fees as a lesser evil than no-privatization-plus-user-fees, the latter option of which has gained support since the passage and subsequent success of the Prescription Drug User Fee Act of 1992, Pub. L. No. 102-571, 106 Stat. 4491 (1992).

10160 Fed. Reg. at 28,618 .

${ }^{102}$ It should be noted that an amendment was successfully offered by Senator Coats (R-Ind.) during the Senate Labor and Human Resources Committee mark-up of the Kassebaum bill, which would establish a three-year pilot for private review of all medical device applications. See Kent, supra note 81, at 3. Thus, the Coats amendment seeks to expand the temporal and substantive scope of any medical device pilot project in an effort to yield more useful data, as well as to ensure congressional oversight.

${ }^{103}$ The retention of a veto power by the FDA also may be necessary to avoid violation of the constitutional doctrine of nondelegation. See Comment, FDA Reform \& the European Medicines Evaluation Agency, 108 HARV. L. REv. 2009, 2022-23 (1995). 
administrative shell, but instead would continue to be the regnant protector of consumer safety. Products would be judged by the same stringent safety and efficacy standards used today, ensuring the consumer that, no matter what entity conducts the review (public or private), the American "gold standard" of safety and efficacy would remain uncompromised.

Although the average American consumer might not notice anything different postprivatization, significant changes could occur for his/her benefit. A greater number of reviewers, all competing for the business of drug, device, and food additive manufacturers, would have strong market incentives to approve products as expeditiously as possible within the statutory boundaries for safety and efficacy. Thus, safe and efficacious products would be approved more quickly, providing consumers with a greater range of therapeutic choices and, possibly, lower prices. ${ }^{104}$ One of the primary shortcomings of today's FDA - excessive backlogs and delays - potentially could be eliminated under a system of privatized review. The other primary shortcoming of today's FDA - the possibility of monopolistic abuse of power - could be lessened by privatization, if not eliminated. As discussed earlier, ${ }^{105}$ potentially arbitrary or capricious action by the FDA is unchecked by courts reluctant to second-guess agency decisions cloaked in the mantra of safety or efficacy. This lack of judicial oversight, in turn, effectively establishes an irrebuttable presumption of validity to FDA decisions, creating the potential for the FDA to abuse its monopolistic position. Under most privatization scenarios, by contrast, an FDA veto of a third-party reviewer's recommendation would carry a presumption of irregularity, which the agency would bear the burden of overcoming. Thus, in practical terms, if the FDA exercises its veto authority, the rejected applicant would have a greater chance of vindicating its product in court because the FDA would bear the burden of supporting its veto decision with objective proof. This shift in the burden of proof would mean that courts would no longer have to defer to the FDA in the face of conflicting safety or efficacy data, thus re-invigorating the system of checks and balances and empowering courts to provide a meaningful check against potential abuses of FDA power.

${ }^{104}$ Cf. Mitre Study Shows Third-Party Reviews Would Cut FDA Costs, FDA WEEk, Dec. 8, 1995, at 67 (reporting that a study conducted by the Mitre Corp. for the Council on Competitiveness indicates that third-party review of drug manufacturing supplement reviews is less costly than FDA review). No official assessment as to the results of the Mitre pilot project have been released by the FDA, and unofficial assessments are mixed. The pilot, which was initiated by the Bush Administration in 1992, reviewed five NDA supplements in an average time per supplement of approximately four months and an average cost of $\$ 48,000$ per supplement. See FDAers Could Make, Break Third Party Review: Concerns Raised with Mitre NDA Test, Med. Device ApProval LetTer, Apr. 1, 1996, available in LEXIS, NEXIS Library, Nwltrs File; see also Louis W. Sullivan, Outside Review Necessary for FDA to Fulfill Mission, Roll CaLl, June 10, 1996, available in LEXIS, NEXIS Library, Curnws File (noting that review by Mitre averaged two to four months per supplement, compared to an average of 28.3 months for supplement review of other products by the FDA). In his testimony before the Senate Labor and Human Resources Committee on February 21, 1996, FDA Commissioner Kessler asserted that the Mitre pilot did not shorten review times. See David A. Kessler, Comm'r, FDA, Testimony before the Senate Labor and Human Resources Comm., Feb. 21, 1996, available in LEXIS, NEXIS Library, Curnws File (stating, in response to questioning by Sen. Frist, that Mitre review "didn't shorten the time .... [I]t allowed us to hire an additional body [Mitre], but it still ended up being reviewed by the [FDA] supervisor."). The Prescription Drug User Fee Act ended the Mitre pilot project by prohibiting the use of user fees to pay for third-party reviews. See Jill Wechsler, More With Less, PharmaCEUTICAL ExEC., Apr. 1995, at 16; see also Sen. Kassebaum remarks during the hearing before the Senate Labor and Human Resources Comm., Feb. 21, 1996, available in LEXIS, NEXIS Library, Curnws File (noting that the Kassebaum bill would lift the PDUFA restriction). Given the limited scope and duration of the Mitre pilot, objective comparisons with current FDA review procedures is extremely difficult.

${ }^{105}$ See supra note 20 and accompanying text. 


\section{B. The Risks of Privatization}

Privatization is, of course, not without its risks. Skeptics of privatization raise many legitimate questions. Who are these third-party reviewers? Will they have the same concern for public safety as does the FDA? Can they be prevented from colluding with the industries that pay them for their review? Will private reviewers engage in a "race to the bottom" to attract and retain business? The question for policymakers is whether these perceived risks are real and, if so, whether they are outweighed by the potential benefits of privatization. Thus, it is essential to analyze these risks before concluding that privatization presents a net benefit to consumers.

\section{Foreign Governmental Agencies}

There is significant variation between the drug, device, and food additive laws of various countries. Thus, each category requires separate analysis.

a. Drugs. The FDA already has taken several steps to recognize the legitimacy of foreign drug agencies. For example, the FDA already has approved several NDAs that were based on some degree of foreign data. ${ }^{106}$ Moreover, the FDA has been an active participant in the recent International Conference on Harmonization, which attempted to establish guidelines to assist in harmonizing drug regulations between the European Union (EU), the United States, and Japan. ${ }^{107}$

Thus far, however, the FDA steadfastly has refused to grant any guaranteed weight to foreign drug approval data or decisions. The privatization proposals before Congress, by contrast, seek to do just that. The most likely candidates to receive such guaranteed weight that have emerged thus far are the EMEA and the British CSM. Senator Kassebaum's bill, for example, permits either the EMEA or the CSM to grant deemed approval status in the United States in the absence of a timely FDA veto. ${ }^{108}$ The advisability of permitting deemed approval status for European-approved drugs can be reduced to one question: can foreign bodies such as the EMEA or CSM be trusted to do as good a job of protecting the consumer as the FDA? To answer this question, it is necessary to discern precisely what these entities do, how they do it, and how well they have carried out their missions.

The EMEA is a relative newcomer on the drug approval scene. It was established in $1993^{109}$ as a by-product of the Maastricht Treaty ${ }^{110}$ and became operational on January 1,1995 . The EMEA provides a centralized procedure for the approval of pharmaceutical products for EU Member States. ${ }^{111}$ For biotechnology products, resort to the

106 See Eric M. Katz, Europe's Centralized New Drug Procedures: Is the United States Prepared to Keep Pace?, 48 Food \& Drug L.J. 577, 581 (1993).

${ }^{107}$ See generally Joseph G. Contrera, Comment, The Food \& Drug Administration \& the International Conference on Harmonization: How Harmonious Will International Pharmaceutical Regulations Become?, 8 ADMIN. L.J. 927 (1995).

${ }^{108}$ S. 1477 , supra note $80, \S 404$.

${ }^{109}$ Council Regulation 2309/93 of July 22, 1993, laying down Community procedures for the authorization and supervision of medicinal products for human and veterinary use, and establishing a European Agency for the Evaluation of Medicinal Products, 1993 O.J. (L 214) 1.

${ }^{110}$ See 1992 O.J. (C 224)1; 1992 O.J. (C 191)1, 95, 109. The Maastricht Treaty established the EU.

${ }^{111}$ See Richard F. Kingham et al., The New European Medicines Agency, 49 Food \& Drug L.J. 301, 301 (1994). There are currently 15 Member States in the EU: Austria, Belgium, Denmark, Finland, France, Germany, Greece, Ireland, Italy, Luxembourg, the Netherlands, Portugal, Spain, Sweden, and the United Kingdom. 
centralized EMEA approval process is mandatory, supplanting previous nation-by-nation review; all other pharmaceutical products may opt to either obtain approval by the centralized procedure of the EMEA or seek approval by one or more individual Member States. ${ }^{112}$

For products seeking approval via the centralized procedure of the EMEA, the first step is to obtain a favorable recommendation of the Committee for Proprietary Medicinal Products (CPMP), which is comprised of two representatives from each Member State's governmental review authority, with one or more CPMP members serving as the primary reviewer for each application. ${ }^{113}$ Following closed-door review of an application, the CPMP issues a recommendation, based on a majority vote, within 210 days. ${ }^{114}$ If the recommendation is favorable, it is forwarded to the EU Commission and its Standing Committee on Medicinal Products for Human Use, which have an additional ninety days to issue their opinions. ${ }^{115}$ If the Standing Committee and the Council agree, their decision is final, and approval will permit the applicant to market the product throughout the EU - a market that is $370,000,000$ consumers strong. ${ }^{16}$ If the Standing Committee and the Commission disagree, the final decision will rest with the Council of the European Union. ${ }^{17}$

Firms that opt to obtain product approval by the decentralized method, by contrast, must first obtain approval by an individual Member State. Thereafter, the manufacturer may seek approval on a nation-by-nation basis or may opt for the more streamlined route of petitioning other Member States for "mutual recognition." 118 Mutual recognition may be denied by a Member State only if the Member State can demonstrate that the quality, safety, or efficacy of the product presents a health risk. ${ }^{119}$ Should a Member State desire to deny mutual recognition, a mandatory, binding arbitration proceeding will be begun by the CPMP, which will issue its opinion within ninety days. ${ }^{120}$ The CPMP's arbitration decision is handled in the same manner as a centralized application would be, with the CPMP's recommendation forwarded to the European Commission and the Standing Committee, and with any disagreement between these two bodies being decided by the Council of the European Union. ${ }^{121}$

A significant - and often neglected - feature of the European scheme is that drugs approved by the national authorities of individual EU Member States are entitled to mutual recognition by other Member States unless a Member State determines that "there are grounds for supposing that the authorization of the medicinal product concerned may present a risk to public health"122 (particularly after 1998, when mutual recognition becomes the sole available decentralized approval procedure). Thus, under

\footnotetext{
${ }^{112}$ Regulation 2309/93, supra note 109 , at 3.

${ }^{113}$ Id. at 16; see also Kingham, supra note 111, at 304, 306.

${ }^{114}$ Regulation 2309/93, supra note 109, at 4; see also Kingham, supra note 111, at 306.

"1s Regulation 2309/93, supra note 109; see also Kingham, supra note 111, at 307.

${ }^{116}$ Patrick Smyth, Three More Countries Join the Biggest Economic Club in the World, IRISH TimEs,

${ }^{117}$ Regulation 2309/93, supra note 109, art. 10.2, at 5; art. 73, at 20. See Kingham, et al., supra note

${ }^{118}$ Beginning in 1998, mutual recognition becomes mandatory in the sense that once a firm opts to travel the decentralized route, it cannot submit separate nation-by-nation applications but instead must petition for mutual recognition. Council Directive 93/39/EEC of June 14, 1993, 1993 O.J. (L 214) 1, 24.

${ }^{119} \mathrm{Id}$. art. 3.1, at 26; see also Kingham, supra note 111 , at 311 .

${ }^{120}$ Council Directive 93/39, supra note 118, art. 1.7, at 24; see also Kingham, supra note 111, at 312 .

${ }^{121}$ Council Directive 93/39, supra note 118, art. 3.1, at 26-28; see also Kingham, supra note 111, at

${ }^{122}$ Regulation 2309/93, supra note 109, art. 3.1, at 26; see also Kingham, supra note 111, at 310-11.
} Jan. 2, 1995, at 10. 111, at 307. 311. 
European law, the decentralized mutual recognition procedure appears to establish a "presumption of approval" that individual Member States must overcome if they wish to deny mutual recognition. Disagreement by one Member State with another Member State's approval triggers automatic arbitration by the CPMP, whose decision then becomes finalized by the action of the European Commission and its Standing Committee. In effect, this decentralized procedure, particularly after 1998, grants automatic mutual recognition unless a disagreement develops amongst Member States, in which case the centralized European bodies step in to resolve the dispute. Thus, it is an open question as to whether any FDA reform law that granted deemed approval status for drugs approved by the EMEA also could be construed to grant deemed approval status for drugs approved by an individual Member State (e.g., Germany or Italy), because products approved via the decentralized procedure gain their approved status either by statutorily authorized mutual recognition or, in the case of disagreement among Member States, by direct EMEA approval.

Senator Kassebaum's bill, for example, could be construed to create this possibility, as it grants deemed approval status to any drug, biological product, device, or food additive that "has met the marketing requirements of the European Union . . . ."123 Because a drug approved via the decentralized procedure arguably has met the "marketing requirements" of the EU, the Kassebaum language could be construed to grant deemed status to drugs approved not just by the centralized procedure, but also to drugs approved by individual EU Member States that have been granted mutual recognition. Such a broad grant of deemed approval status would raise greater concerns than if deemed status were limited to drugs approved by the centralized procedure of the EMEA. Approval by Portuguese or Greek drug authorities, for example, would result in a presumption of safety and efficacy absent an FDA veto.

Perhaps the only way to assess the wisdom of such a policy is to compare the safety records of drugs approved by individual EU Member States with drugs approved by the FDA. A recent study by the Public Citizen Health Research Group found that, of fiftysix drugs withdrawn for safety reasons from the United States, in the United Kingdom, France, and Germany between 1970 and 1992, thirty-one were approved in France, thirty in Germany, twenty-three in Britain, and nine in the United States. ${ }^{124}$ These statistics may seem to indicate that the European drug approval agencies are not as successful as the FDA in preventing hazardous drugs from reaching the market. These raw numbers, however, mean nothing unless they are placed in context, and this can be achieved only by expressing the number of withdrawn drugs as a percentage of total drugs approved. Thus, because the drug approval agencies of these countries approved many more drugs than the FDA during this period, the actual percentage of drugs withdrawn from the market due to safety concerns may be comparable to that in the United States.

In contrast to the EMEA, Britain's CSM has a longer track record to which more meaningful comparisons with the FDA may be made. In the period from 1990 to 1994, a total of 104 new drugs were approved for sale by either the FDA, the CSM, or both. Of these 104 new drugs, fifty-eight (55.8\%) were approved for sale in both countries, twenty-eight (26.9\%) were approved for sale in the United Kingdom only, and eighteen $(17.3 \%)$ were approved for sale in the United States only. Thus, it appears that, at least

${ }^{123}$ S. 1477 , supra note $80, \S 404$.

124 Some of the drugs were withdrawn by more than one country. See Study Says U.S. Has Better Barrier to Bad Drugs Than Europe. WASH. Post, Feb. 3, 1995, at A9; see also Hilts, supra note 63, at 24. 
in recent years, the FDA has been more reluctant than the CSM to approve new drugs. The U.K. consumer, therefore, has more drugs from which to choose. But has this increased choice resulted in an increased risk to U.K. consumers? The answer appears to be "no." While two of the twenty-nine drugs approved only by the CSM and none of the eighteen drugs approved only by the FDA subsequently were withdrawn from the market due to safety concerns, ${ }^{125}$ the greater number of drugs available to U.K. consumers means that, expressed as a percentage of available drugs, safety problems are no more prevalent in the United Kingdom than the United States: approximately four percent of drugs on the U.K. market are withdrawn due to safety concerns, versus three percent in the United States. ${ }^{126}$

Although the drug approval agency of the United Kingdom may provide an adequate level of consumer protection, the question still remains whether other EU Member States' (e.g., Portugal's, Greece's, or Italy's) drug approval processes should be extended the same level of confidence. Because of the paucity of information available on the number of drug approvals and withdrawals in many such countries, it would seem advisable, at least at this point, to deny deemed approval status in the United States for drugs approved by these countries. Thus, the language of the Kassebaum bill (or any reform bill ultimately enacted) may need to be more narrowly circumscribed, to specify that deemed approval status will be granted only to those drugs approved by the centralized procedure of the EMEA or by the CSM.

While the CSM or EMEA may provide an adequate level of consumer protection, another problem nonetheless remains: granting deemed approval status for drugs approved by these agencies may erode consumer confidence in the drug supply. Thus, although the percentage of "bad" drugs may remain the same if deemed approval status for drugs approved by the CSM or EMEA were permitted, the increase in the raw number of "bad" drugs may nonetheless taint public perception. Americans' tolerance for risk appears to be lower than that of Europeans. ${ }^{127}$ Thus, the possibility exists that the FDA's image as the "gold standard" for consumer protection may be tarnished by permitting deemed approval status for EMEA- or CSM-approved drugs. This possibility, however, seems remote, for it is only if the FDA fails to exercise its veto authority in a conscientious manner that the American perception of risk would not be taken into account. Thus, if the FDA takes it veto authority seriously, a drug approved by the CSM or EMEA that presents an unacceptable level of risk to Americans would be vetoed.

b. Medical Devices. As with drugs, the Kassebaum bill would grant deemed approval status to any device that "has met the marketing requirements of the European

${ }^{125}$ The two drugs withdrawn were centoxin and remoxipride. See O\&I Hearings, supra note 15, at 65 (testimony of William Schultz, Deputy Comm'r for Pol'y, FDA).

${ }^{126}$ Id . at 151 (testimony of Louis Lasagna, Dir., Tufts Center for the Study of Drug Development). This statistic appears to reflect the results of a 20-year study (1974-1993) that compared the number of new chemical entities and new biological entities that were withdrawn for safety reasons by the United States, the United Kingdom, and Spain. While the study revealed that during this 20 -year period, 20 drugs were withdrawn from the United Kingdom, 16 from Spain, and 10 from the United States, these withdrawals represented the same percentage of drugs available on the respective markets - roughly three to four percent. See O.M. Bakke, et al., Drug Safety Discontinuations in the United Kingdom, the United States, \& Spain from 1974 through 1993: A Regulatory Perspective, Clinical, Pharmacology \& Therapeutics, July 1995, at 108-17.

${ }^{127}$ See, e.g., Sheila Jasanoff, Cultural Aspects of Risk Assessment in Britain and the United States, in Social and Cultural Construction of Risk 359, 385 (Branden B. Johnson \& Vincent T. Covello eds., 1987) (noting that "[i]n Britain, scientists and governmental decision makers are certain to recognize a risk only when there is persuasive evidence of actual harm . . . whereas in the United States a risk may be acknowledged where there is no direct proof of injury to the public"). 
Union or the United Kingdom." ${ }^{28}$ The EU has adopted three uniform medical device directives that must be implemented by Member States (including the United Kingdom): (1) a general medical device directive, ${ }^{129}(2)$ a special directive for active and implantable devices, ${ }^{130}$ and (3) a special directive for in vitro diagnostic devices. ${ }^{131}$ Products that satisfy the minimum requirements of the applicable directive are permitted to display the distinctive letters "CE" to certify compliance, and such products may move freely among EU Member States. ${ }^{132}$

The general device directive, which became effective in all Member States on January 1, 1995, establishes four classes of devices (I, Ila, IIb, and III, listed in increasing order of complexity and risk). ${ }^{133}$ The active and implantables directive, which became effective in all Member States on January 1, 1993, requires all active or implantable devices to meet standards regarding design, construction, performance, and safety. ${ }^{134}$ Standards are established for each class, and medical device manufacturers generally are permitted to self-classify their products, subject to review by governmental agencies of individual Member States. ${ }^{135}$ The in vitro directive sets forth a general scheme of self-certification and marketing notification for devices intended to provide an in vitro diagnosis of disease. ${ }^{136}$

While there is not yet much information regarding the track record of the EU medical device directives, it seems reasonable to say that, at least on the surface, they provide a system of regulation highly analogous to the Federal Food, Drug, and Cosmetic Act (FDCA). ${ }^{137}$ The special requirements applicable to active and implantable devices, for example, are as or more stringent than the requirements applicable to Class III devices in the United States. The EU standards for other devices likewise seem analogous to the sliding-scale concept of regulation contained in Class I and Class II devices in the United States. Because comparison between the EU and the United States is rather difficult at the early stages of implementation of the various EU medical device directives, however, it may be advisable to delay deemed approval status for medical devices approved by EU Member States.

c. Food Additives. The Kassebaum bill likewise permits deemed approval status for food additives approved by the EU or the United Kingdom. ${ }^{138}$ Because the EU has not adopted uniform food additive safety standards, granting deemed approval status for food additives is premature. Moreover, in the United Kingdom, the governmental agency responsible for food regulation and safety, the Ministry of Agriculture, Fish-

${ }^{128} \mathrm{~S}$. 1477 , supra note $80, \S 404$.

${ }^{129}$ Council Directive 94/42/EEC, 1993 O.J. (L 169) 1.

${ }^{130}$ Council Directive 90/385/EEC, 1990 O.J. (L 189) 17. Active devices are those that use an unnatural source of power. Implantable devices are those that are intended to be introduced into and remain inside the body. An example of an active medical device is a pulse generator for a pacemakers. An example of an implantable medical device is a drug administration device that is implanted into the skin. See Linda $\mathbf{R}$ Horton, Medical Device Regulation in the European Union, 50 Food \& DRUG L.J. 461, 466 n.29 (1995).

${ }^{131}$ Proposal for a European Parliament and Council Directive 95/C 172/02 on in vitro diagnostic medical devices, 1995 O.J. (C 172) 21.

${ }^{132}$ See Horton, supra note 130 , at 467.

${ }^{133} I d$. at 466,469 . Member States are permitted to operate parallel systems of regulation until June 14 , 1998. Id. at 466.

${ }^{134} I d$. at 466.

${ }^{135}$ Council Directive 90/385/EEC, supra note 130.

${ }^{136}$ Proposal for a European Parliament and Council Directive 95/C 172/02, supra note 131.

${ }^{137}$ See Pub. L. No. 75-717, 52 Stat. 1040 (1938), as amended 21 U.S.C. $§ \S 301$ et seq. (1994).

${ }^{138}$ S. 1477 , supra note $80, \S 404$. 
eries, and Food (MAFF), has been involved in a recent rash of criticism. ${ }^{139}$ Critics claim, for example that MAFF intentionally concealed an outbreak of listeriosis, a food-borne illness sometimes found in patè and soft cheeses, that caused over sixty deaths. ${ }^{140}$ In addition, recent waffling by MAFF officials on the safety of beef infected with bovine spongiform encephalopathy (BSE), which causes the "mad cow" disease, ${ }^{141}$ has left many in the United Kingdom calling for structural reform of the agency. ${ }^{142}$ In particular, critics of MAFF contend that it has an inherently conflicting mission of promoting agriculture on the one hand and protecting the consumer on the other. ${ }^{143}$ Thus, consumer groups, academics, and even the food industry now seem to support segregating these two responsibilities into separate agencies, in much the same way that the U.S. Department of Agriculture and the FDA divide responsibilities in the United States. ${ }^{144}$ Given the current vote of no confidence by U.K. consumers in MAFF, it may be imprudent to permit deemed approval status for food additives approved for sale in the United Kingdom.

\section{Private Domestic Reviewers}

With regard to potential third-party domestic reviewers, the problem posed by cultural differences in risk perception disappears, but a new problem emerges: can nongovernmental entities be trusted to the same extent as governmental entities such as the CSM, the EMEA, or the FDA? Will such private reviewers have a greater incentive to shirk their responsibility to ensure safety or efficacy for the sake of making more money?

As an initial matter, it should be noted that there appear to be many private domestic entities that could take over all, or a significant part, of the FDA's review function. Organizations such as Underwriters Laboratories, for example, could conduct much of the testing for electrical medical devices, ${ }^{145}$ while the Federation of American Societies of Experimental Biology (FASEB) could conduct much of the testing for food additives. ${ }^{146}$ Likewise, IRBs, ${ }^{147}$ medical schools, research institutes (such as the Mitre Cor-

${ }^{139}$ See Michael Durham, Public Health: Safe to Eat? We'll Be the Judge of That, OBSERver (London), Dec. 10,1995 , at 11 .

${ }^{140}$ See Simon Hinde \& David Leppard, Counting the Cost of a Deadly Delay, Sunday Times (London), July 9, 1995, available in LEXIS, NEXIS Library, World File, Curnws Subfile.

${ }^{141}$ Some scientists believe that the ingestion of BSE-infected beef may cause a terminal disease in humans known as Creutzfeldt-Jacob Disease. See "Mad Cow" Monkeys Similar to Creutzfeldt-Jacob in Humans, JAPAN Econ. NewswiRE, June 27, 1996, available in LEXIS, World Library, Curnws File. BSEinfected beef also has been found in Switzerland and France. See Swiss Say Mad Cow Cases Stabilising, REuter Econ. Community Rep., July 5, 1996 (stating that 35 cases of BSE were reported in the first six months of 1996); see also Herd Destroyed After France's 21st Mad Cow Case, Reuter Econ. Community REP., July 8, 1996 (stating that 21 cases of BSE have been uncovered in France since 1990).

142 See Durham, supra note 139, at 11.

${ }^{143} \mathrm{Id}$. Professor Tim Lang of the Thames Valley University, claims that "BSE is only the latest in a series of food scandals. From the 1980s we have seen a whole raft of problems which are the downside of a food revolution which began after the Second World War. MAFF then took a decision to maximise [sic] food production, and it has made that its raison d'etre since. It pressed the green button to increase yields and since then we have seen the emergence of all sorts of health problems." Id.

${ }^{14}$ Id. Michael Young, Director of the Food Safety Advisory Centre (a trade association for supermarkets) stated that "[t]here is a need for a clear separation of political power from regulatory issues about public health." Id.

${ }^{145}$ See Effort to Privatize Drug Review Grows, Modern HealthCare, June 26, 1995, at 54 (statement of Robert Williams, Manager of Standards and Research, Underwriters Labs.).

${ }^{146}$ Indeed, the FDA has contracted with FASEB on numerous occasions in the past to conduct safety and efficacy evaluations for "generally recognized as safe" food additives. See Food Additive Hearings, supra note 3, at 5; accord Hutt, supra note 39 , at $48-49$. 
poration and the RAND Corporation), and private nonprofit organizations (such as the National Academy of Sciences or the United States Pharmacopeia) could shoulder much of the burden of drug testing. Could these entities, however, conduct their reviews without being corrupted by the lure of profits dangled by companies seeking a positive recommendation for their product?

The temptation to place profits over consumer safety mandates that any reform scheme permitting private review must contain stringent safeguards to prevent corrupting conflicts of interest. This is especially true if the direct contracting approach (such as that contained in the House Task Force bills) is adopted, because permitting product applicants to have a direct contractual relationship with the private reviewer creates inherent incentives for the applicant to forum shop and for the reviewer to provide a favorable review. Under either a direct or an indirect contracting approach, however, there is potential for a conflict of interest that is not present in the same degree when the government is the sole available reviewer. This does not mean, however, that the current system of monopolistic governmental review is immune to conflicts of interest the generic drug scandal is perhaps the most obvious example - but there is also a chorus of concern from consumer groups who worry that the present FDA is "in bed" with the industries it regulates due, in part, to the ubiquitous revolving career door. ${ }^{148}$ In addition, consumer groups charge that the industries regulated by the FDA have greater access to it and that, as a result, consumer concerns are not adequately taken into account by the agency. ${ }^{149}$ Thus, under a system of privatized review, the question is whether regulated industries will be able to exert greater influence over private third-party reviewers than they currently exert over the FDA.

Despite consumer groups' perception that industry has the ear of the FDA, the FDA's preeminent concern has been to protect consumers. Thus, while the FDA may interact more often with industry representatives, such intimacy more likely belies the FDA's frequent regulatory actions against industry than any scheme to ignore consumers. Arguably, therefore, privatization merely would exchange one set of potential biases for another - that is, a bias toward undue caution in the name of consumer protection in exchange for a bias toward undue speed in the name of profit-making. This shift in bias is potentially minacious, but it may be diluted by taking stringent measures to ensure that both the FDA and the private reviewers are accountable to the public.

How would such accountability be ensured? First, as discussed earlier, reserving a veto power to the FDA will force the agency to remain accountable to the consuming public and will provide a mechanism by which it may continue to express its traditional pro-consumer bias. Second, continued congressional oversight of the FDA's veto power will provide an added measure of security by holding the FDA accountable if it fails to fulfill its statutory obligation and merely rubber-stamps private reviewers' recommendations. Third, private third-party reviewers can be held accountable for their recommendations by drafting stringent conflict-of-interest prohibitions similar to that used in other areas of extensive government contracting, such as in the Department of Defense and the Department of Energy. Fourth, any incentives on the part of product applicants to forum shop could be minimized by devising quantitative limits on the reviews that any single private reviewer could conduct for the applicant during a given time period.

\footnotetext{
${ }^{147}$ See, e.g., H.R. 1742, supra note $68, \S 5$ (permitting IRBs to approve applications for investigational new drugs absent a veto by the FDA within 30 days).

${ }^{148}$ See Alexander M. Schmidt, FDA-Industry Relationships in the Future, in Regulating Change: The Regulation of Foods, Drugs, Medical Devices \& Cosmetics in the 1990s, at 121 (1989).

${ }^{149} \mathrm{Id}$. at 119-21.
} 
Fifth, any congressional reform is likely to require that private reviewers obtain some form of accreditation or certification by the FDA, so the agency could ensure via auditing that private reviewers meet minimum standards for personnel, training, and good science. Indeed, it is even conceivable that, as part of the accreditation process, the FDA could design and require adherence to certain minimum standardized review procedures, the so-called "good review practices." 150 Finally, there is a significant and of ten forgotten extra dose of oversight that limits the potential for recklessness on the part of third-party reviewers, at least with regard to drug and medical device reviews: healthcare payors (primarily managed care entities).

Health-care payors are, by definition, sophisticated intermediaries that determine which drugs and medical devices will be paid for by the health-care policies they sponsor. If these payors do not have confidence in the quality of the review conducted by a particular private reviewer, presumably they would not pay for drugs or devices approved by the reviewer. Thus, while some drug or device manufacturers may have an incentive to patronize "low-quality" private reviewers (although the existence of truly "low-quality" reviewers is unlikely assuming a requirement of FDA accreditation) in the hopes of obtaining a positive recommendation, they may find that (assuming arguendo that the FDA merely rubber stamps the recommendation) the drug or device so approved will not be covered by insurance. In short, a positive recommendation by a private reviewer with a bad reputation conceivably could obtain FDA approval, but the market for a drug or device approved by a shoddy reviewer likely would be severely limited because payors have no incentive to place a drug on a formulary or to provide coverage for a medical device if they have questions about the product's safety or efficacy. The concerns of private payors, therefore, will provide both ex ante and ex post incentives for high-quality reviews. Ex ante, they will pressure the FDA to establish rigorous accreditation criteria and to carefully assess the recommendations of private reviewers. Ex post, they will not provide coverage for products unless the private reviewer conforms to essential safety and efficacy review criteria.

Perhaps those most concerned about the accountability of private domestic reviewers are concerned about the larger issue of preserving democratic ideals. There seems to be almost a visceral reaction against privatization by some who are afraid that the process will take responsibility for the safety of the nation's food and medical products out of the hands of "the People" and into the hands of profit-driven industry. With adequate safeguards such as FDA accreditation and veto power, the retention of current safety standards (and the FDA's ability to enforce those standards), together with continued congressional oversight, these fears could be allayed.

Industries regulated by the FDA also may have legitimate reservations about privatization that should be addressed. The most important of these concerns is the question of whether privatization will undermine public confidence in the industries' products. The FDA has provided the global "gold standard" for ensuring safety and efficacy; the "gold standard" has real economic value to products that receive the FDA stamp of approval. What will a third-party reviewer's stamp be worth? Despite the FDA's difficulties, a 1995 poll revealed that seventy-two percent of Americans believe that the American food and drug supply is safer than that of any other country. ${ }^{151}$ Where

${ }^{150}$ The FDA has admitted that basic good review practices are achievable and the agency currently is devising them for use by their in-house reviewers. See Koberstein, supra note 99, at 40 (statement of Dr. Janet Woodcock, Dir., Ctr. for Drug Evaluation and Research, FDA).

131 See Saul Friedman, Republicans Targeting FDA: Deep-Pocket Drug Companies Backing Efforts to Shut Agency, NewSDAy, Feb. 27, 1995, at A4. A 1995 survey conducted by the Food Marketing Institute showed that $77 \%$ of consumers are completely or mostly confident in the safety of the food supply (a four 
would over-the-counter drug manufacturers such as the makers of Tylenol and Sudafed be if it were not for swift and decisive action by the FDA after evidence of producttampering surfaced? ${ }^{152}$ Is it not because of vigilant FDA inspection and enforcement that Americans generally do not worry about their food supply being endangered by filth or microbiological contamination? American food, drug, and device companies have thrived over the last century in large part because the FDA has fulfilled its role as a vigilant enforcer of high standards.

Privatization will not change this. The FDA's ability to enforce the FDCA would not be altered post-privatization; only the review function of the FDA will be out-sourced because that is the only area in which the FDA appears to be unable to keep adequate pace with the industries it regulates. Thus, as long as the FDA retains its enforcement authority and conscientiously exercises its veto power, consumer confidence in the products regulated by the FDA likely would not suffer as a result of privatization.

Another potential concern of industry - which ironically is raised most often by non-industry groups opposed to privatization - is the concern that third-party reviewers may not turn out to be speedier than the FDA. Although user fees presumably would give private domestic reviewers the resources necessary to assess product applications within a reasonable time, delays might continue to occur. Highly advanced products, particularly those that are completely new molecular compounds, arguably are so complicated that they will take an inordinate amount of time to review. If this is true, why not acknowledge that the agency's sluggish review is due to genuine scientific uncertainty or inadequate resources, and give the FDA greater resources to do its job? ${ }^{153}$

Increasing FDA resources could, in theory at least, speed FDA review times. Indeed, the 1992 Prescription Drug User Fee Act generally is credited with lowering review times for drug approval applications. ${ }^{154}$ Whether FDA resources should be increased, however, is not the center of debate; the question is how FDA resources should be increased: by hiring additional government reviewers or by contracting with private reviewers. Either approach likely will yield efficiency gains in the short run. In the long run, privatization seems more likely to yield lasting efficiency gains because the incentive for private reviewers to behave efficiently - the market incentive - is perpetual. By contrast, the government's incentive to behave efficiently - adverse publicity and political pressure - is likely to wax and wane over time. Thus, as one FDA expert humorously (but astutely) noted, doubling the FDA's resources would result in either

percent increase from 1994). See Carol A. Bodensteiner, Predicting Public \& Media Attention Span for Social Issues, PuB. REL. Q., June 22, 1995, at 14.

${ }^{152}$ See, e.g., Jack Broom, et al., Sixth Package of Tainted Sudafed Discovered, Seattle Times, Mar. S, 1991, at Al (noting that FDA officials inspected over 20,000 Sudafed capsules in the Seattle area after evidence of tampering surfaced); Michael deCourcy Hinds, Tylenol Maker Recalls Capsules After Strychnine Incident in West, N.Y. Times, Oct. 6, 1982, at Al (noting that FDA Commissioner Hayes announced that recent product tamperings indicate a need for prophylactic regulations "to restore consumer confidence in over-the-counter products.").

${ }^{133}$ The Congressional Budget Office (CBO) estimates that the Kassebaum bill, which permits private review only if the FDA fails to meet statutory deadlines, would cost the federal government $\$ 555,000,000$ over the next six years. See FDA: CBO Estimates Budgetary Impact of Reform Bill at $\$ 555$ Million, BNA Health Care Daily, July 3, 1996, available in LEXIS, Health Library, BNAHCD File. The CBO estimate thus implicitly acknowledges that the FDA, if it is going to review products in a more efficient manner, will require a significant injection of taxpayer dollars.

${ }^{154}$ See We're Not Dragging Our Feet on New Drugs, WASH. Post, Apr. 13, 1995, at A-31 (op-ed article by William Schultz, Deputy Comm'r for Pol'y, FDA, crediting PDUPA for speeding review time); Morton Mintz, The Cure That Could Kill You: FDA Reforms are Bad Medicine, Wash. Post, July 14, 1996, at $\mathrm{C}-1$ (same). 
one of two things: it would cut the review time in half, or it would double the review time. ${ }^{155}$ Given the monopolistic position of the FDA, the latter result seems more probable because an increase in resources could provide more manpower with which to expand regulatory requirements or scrutinize product applications, thus delaying decisions even more. There is no guarantee that an increase in FDA resources would result in streamlined product approvals, particularly in the long run after congressional and media attention diminishes. More important, increasing FDA resources in lieu of substantive reform merely plumpens the "elephant" and decreases the chances that he will ever "dance." The problems of the FDA go much deeper than the availability or amount of its resources. As this article has attempted to demonstrate, the problems fueling the FDA reform movement are traceable to the agency's monopolistic position that provides no long-term incentives for it to behave in the same competitive manner as private reviewers.

\section{CONCLUSION}

The products under the jurisdiction of the FDA hold enormous potential to improve, and even save, lives. The current system of review results in undue delay and hence undue harm. To minimize such delay-induced harm, the root of the delay - a monopolistic system of product review that inherently breeds excessive caution and costly, autocratic regulation - must be acknowledged and severed. The goal of FDA privatization is to inject a healthy dose of competition into product review, thereby breaking the extant monopoly and speeding the review of potentially life-saving products. Competition and consumer safety are not mutually exclusive concepts. With the proper safeguards, privatization of the FDA review process provides the greatest longterm potential for speeding review, enhancing global competitiveness, and saving lives.

iss Remarks by Peter Barton Hutt, Partner, Covington \& Burling, at Harvard University's School of Public Health (Feb. 1996). 